\title{
Teknologi penguraian limbah jamur untuk peningkatan varian produksi petani jamur Desa Umbansari
}

\author{
Dianita Wardani \\ Politeknik Caltex Riau \\ dianita@pcr.ac.id
}

\begin{abstract}
Abstrak. Jamur tiram adalah salah satu jenis jamur yang dibudidayakan secara komersial di Indonesia. Jamur tiram sudah dapat dipanen dalam waktu 1-3 bulan saja. Sehingga dari sisi bisnis jamur tiram sangat menguntungkan. Namur dikarenakan modal usaha untuk membeli bibit jamur yang dipasok dari luar daerah berkurang maka dari 5 petani jamur yang tetap bertahan tinggal 2 petani. Salah satunya berada di desa Umban Sari Atas Kecamatan Rumbai Kota Pekanbaru. Untuk itu dibutuhkan modal usaha yang lebih besar dari sebelumnya. Disinilah timbul ide untuk meningkatkan hasil variasi produksi dari jamur tadi. Salah satunya memanfaatkan limbah baglog jamur yang sudah tidak termanfaatkan menjadi briket baglog jamur. Dengan menggunakan teknologi limbah baglog jamur tiram dapat diuraikan dan diubah menjadi briket baglog jamur. Briket limbah baglog jamur tiram tadi tentu saja dapat menjadi salah satu bahan bakar alternatif yang dapat dijual dan dijadikan varian hasil produksi selain jamur. Dengan demikian maka diharapkan dapat meningkatkan pendapatan petani jamur. Dalam PKM ini beberapa permasalahan yang dihadapi yakni: (1) peningkatan pemanfaatan limbah baglogjamur sebagai varian produk pengembangan jamur yang sudah tidak termanfaatkan atau limbah baglog agar dapat meningkatkan hasil produksi dan pendapatan; dan, (2) pengadaan mesin press manual agar mendapatkan kepadatan briket baglog jamur yang sama. Luaran dari PKM ini adalah pengenalan teknologi penguraian limbah baglog jamur tiram sebagai pengembangan produk jamur dan pembuatan briket jamur kepada masyarakat petani jamur tiram di desa Umban Sari Atas serta pengadaan mesin press manual untuk pembuatan briket baglog jamur. Selain itu dari PKM ini didapatkan luaran penggunaan proses pembakaran menggunakan briket dari hasil olahan limbah baglog jamur, petani juga dapat menghemat cost untuk pembelian bahan bakar (kayu, sekam padi) sebesar Rp.120.000,- untuk proses pemanasan dan steam bibit jamur setiap bulannya.
\end{abstract}

Kata kunci: baglog jamur; briket; jamur tiram mesin press briket

\begin{abstract}
Oyster mushrooms are one type of mushroom that is cultivated commercially in Indonesia. Oyster mushroom is one type of mushroom that is commercially cultivated in Indonesia. Oyster mushrooms can be harvested within 1-3 months. So that from the business side of oyster mushrooms is very profitable. Namur because the business capital to buy mushroom seeds supplied from outside the area is reduced, then from 5 mushroom farmers who survive only 2 farmers. One of them is in the village of Umban Sari Atas, Rumbai District, Pekanbaru City. For this reason, a larger business capital is needed than before. This is where the idea arises to increase the variation in production from the mushroom. One of them is using baglog mushroom waste which has not been utilized into mushroom baglog briquettes. By using baglog waste technology, oyster mushrooms can be broken down and converted into mushroom baglog briquettes. The oyster mushroom baglog waste briquettes of course can be one of the alternative fuels that can be sold and made into a variant of production other than mushrooms. Thus it is expected to increase the income of mushroom farmers. In this PKM some of the problems faced are: (1) increased utilization of baglogjamur waste as a product variant of fungal development that has not been utilized or baglog waste in order to increase production and income. (2) Procurement of manual press machines to get the same baglog mushroom briquette density. The output of this PKM is the introduction of oyster baglog mushroom waste decomposition technology as the development of mushroom products and the manufacture of mushroom briquettes to oyster mushroom farmers in Upper Umban Sari village and the procurement of manual press machines for making baglog mushroom briquettes. In addition, from the PKM, there is an increase in the production of mushroom farmers, if previously the farmers can harvest 3-4 kg of mushrooms a day, now farmers can harvest mushrooms 5-6 kg per day. After using the combustion process using briquettes from processed baglog mushroom waste, farmers can also save costs for purchasing fuel (wood, rice husk) of Rp. 120,000 for the process of heating and steam mushroom seeds every month.
\end{abstract}

Keywords: oyster mushrooms; briquettes; mushroom baglogs; briquette press machines 
To cite this article: Wardani, D. 2019. Teknologi Penguraian Limbah Jamur untuk Peningkatan Varian Produksi

Petani Jamur Desa Umbansari. Unri Conference Series: Community Engagement 1: 108-112.

https://doi.org/10.31258/unricsce.1.108-112

(C) 2019 Author

Peer-review under responsibility of the organizing committee of Seminar Nasional Pemberdayaan Masyarakat 2019

\section{PENDAHULUAN}

Jenis jamur di Indonesia banyak macamnya contohnya: jamur tiram, jamur merang, jamur kuping dan lainlain. Lebih dari 200 spesies jamur telah lama digunakan sebagai fungsional makanan di seluruh dunia, tetapi hanya sekitar 35 spesies telah dibudidayakan secara komersial (Ariyanto, 2016) Jamur adalah sumber yang kaya nutrisi, terutama protein, mineral serta vitamin B, C dan D. Kandungan utama pada baglog jamur adalah komponen lignoselulosa yang terdiri dari lignin, selulosa dan hemiselulosa. Selulosa merupakan kompenen utama dari lignoselulosa yang terdiri dari unit monomer D-glukosa yang terikat pada ikatan 1,4-glikosidik dengan kandungan sekitar $45 \%$ dari berat kering. Hemiselulosa terdiri dari beberapa unit gula atau heteropolisakarida. Hemiselulosa terikat dengan polisakarida, protein, lignin dan lebih mudah larut dibandingkan selulosa di dalam kayu. Kandungan hemiselulosa berkisar antara 25-30\%, tergantung dari jenis kayunya dan lignin merupakan polimer terbanyak setelah selulosa. Polimer aromatik yang berasosiasi dengan polisakarida pada dinding sel sekunder tanaman dan terdapat sekitar 20-40\%. Komponen lignoselulosa dapat dipecah menjadi monomer- monomer glukosa. Monomer glukosa dapat diperoleh melalui proses hidrolisis, baik secara kimia, fisika dan biologi. Secara kimia dilakukan secara hidrolisis, secara fisika dengan suhu tinggi dan secara biologi dengan pemanfaatan mikroorganisme seperti jamur dan bakteri. Lignoselulosa sering dihidrolisis dengan perlakuan asam, kemudian hidrolisat yang diperoleh digunakan untuk fermentasi bioetanol oleh mikroorganisme seperti ragi. Hidrolisat tidak hanya mengandung glukosa, tetapi juga berbagai monosakarida, seperti xylose, galaktose, mannose, oligosakarida dan mannose (Sinurat, 2012). Sehingga mikroorganisme akan lebih efisien dalam memfermentasikan gula tersebut untuk biomassa. Salah satu hidrolisis secara kimia yang telah dilakukan pada penelitian bioetanol dengan substrat sampah organik yaitu hidrolisis menggunakan cairan asam. Asam dapat memecah polimer glukosa secara acak menjadi gula pereduksi (Byeong and Lee, 2015). Pada saat ini limbah baglog jamur kurang termanfaatkan secara optimal sehingga sering terbuang tanpa adanya recycle limbah baglog jamur sebagai briket. Desa Umbansari terletak di Kecamatan Rumbai Kota Pekanbaru, $\pm 2 \mathrm{~km}$ dari Kampus Politeknik Caltex Riau. Iklim setempat juga sangat mendukung untuk bisa membudidayakan jamur tiram. Tujuan yang ingin dicapai dari program kegiatan pengabdian kepada masyarakat yang dilakukan ini adalah dengan memanfaatkan limbah baglog jamur tiram yang terbuang menjadi varian hasil produk jamur lainnya. Dengan adanya teknologi maka limbah baglog jamur tiram yang terbuang dapat dimanfaatkan dengan cara menguraikannya dan membuatnya menjadi briket baglog jamur tiram (Young and Woon. 2013).

\section{MASALAH}

Pada pengabdian masyarakat ini diharapkan dapat membantu permasalah yang dimiliki oleh mitra, bahwa baglog jamur yang tidak terpakai dan terbuang dapat digunakan lagi dengan menjadikan limbah baglog untuk briket jamur yang mempunyai tingkat efesiensi energi yang tinggi dan mengembangkan varian produk olahan dari jamur dan meningkatkan penghasilan petani jamur. Usaha pertanian jamur ini pun diharapkan dapat lebih berkembang sehingga dapat lebih banyak menyerap tenaga kerja terutama ibu-ibu rumah tangga sekitar untuk dapat meningkatkan kondisi ekonomi keluarga dan masyarakat sekitarnya. Bantuan untuk memberi solusi bagi Mitra juga diharapkan dapat menjadi contoh bagi masyarakat sekitar untuk berkeinginan mempunyai usaha sendiri. Setidaknya, Mitra dapat memberikan pelatihan tentang pemanfaatan limbah baglog jamur.

\section{METODE}

Kegiatan pengabdian ini meliputi beberapa tahapan-tahapan pelaksanaan yang harus dilalui yakni tahapan persiapan dan analisis permasalahan mitra, pelaksanaan serta rencana keberlanjutan program.

Persiapan dan Analisis Permasalahan Berdasarkan uraian pada bagian sebelumnya, diketahui bahwa terdapat 2 (dua) permasalahan yang dihadapi Mitra, yaitu: Pelatihan Penguraian dan Peningkatan Varian 
Peoduksi Jamur (Briket Jamur) Peningkatan produktivitas limbah baglog jamur yang tidak terpakai sebagai briket jamur. Diperlukan beberapa peralatan untuk pembuatan briket baglog jamur yaitu mesin blender atau mesin penghancur baglog jamur dan mesin press briket jamur. Mesin blender atau mesin penghancur baglog jamur digunakan untuk menghancurkan limbah baglog jamur dan mencampurnya. Sedangkan mesin press briket digunakan untuk mencetak briket dari limbah baglog jamur yang telah dibuat.

\section{Pelaksanaan PKM}

Penguraian Baglog Limbah Jamur dan Pembuatan Briket Pembuatan briket jamur mula-mula dilakukan dengan menghancurkan atau menggiling limbah baglog jamur menggunakan mesin penghancur limbah baglog yang akan kita buatkan untuk UKM petani jamur desa Umbansari. Limbah baglog yang sudah hancur kemudian ditambahkan dengan cairan asam dan setelah itu dicetak menggunakan mesin press briket yang akan dibuatkan untuk UKM petani jamur. Hasil briket yang telah dicetak dengan mesin press kemudian kita keringkan terlebih dahulu.

\section{PEMBAHASAN}

Berdasarkan metode pelaksanaan, program kepada masyarakat ini terdiri dari kegiatan: (1) Sosialisasi Penguraian Limbah Baglog Jamur; (2) Pembuatan Mesin Press briket jamur; (3) Pengujian hasil dari kadar briket untuk keperluan industri Berikut ini akan disampaikan hasil dari setiap kegiatan tersebut.

Sosialisasi penguraian limbah baglog bertujuan untuk meningkatkan manfaat ataupun kegunaan dari limbah yang sudah tidak terpakai agar menjadi varian produk yang lebih bermanfaat dan mempunyai daya jual. Sosialisasi dan penyuluhan pemanfaatan baglog bertujuan untuk memberikan wawasan kepada petani jamur akan manfaat limbah baglog jamur yang sudah tidak terpakai untuk meningkatkan pendapatan mitra petani jamur dari limbah baglog yang tidak terfungsikan lagi. Penyuluhan ini terdiri dari pembekalan tentang varian dari limbah baglog. Limbah baglog dapat dirubah menjadi briket dengan ditambahkan cairan asam dengan proses hidroisis asam. Berikut merupakan Gambar 1-4 kegiatan PKM mulai dari proses sosialisasi sampai pembuatan briket limbah jamur.

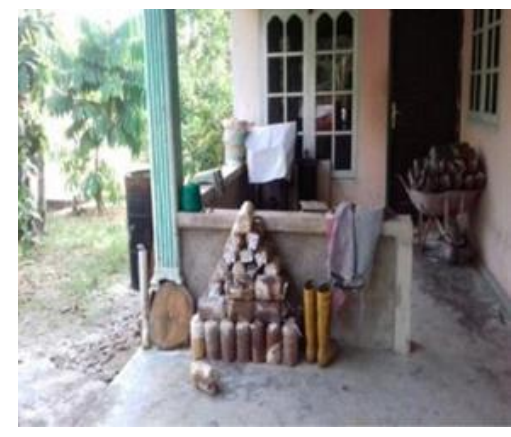

Gambar 1. Limbah Baglog Jamur di Rumah Mitra

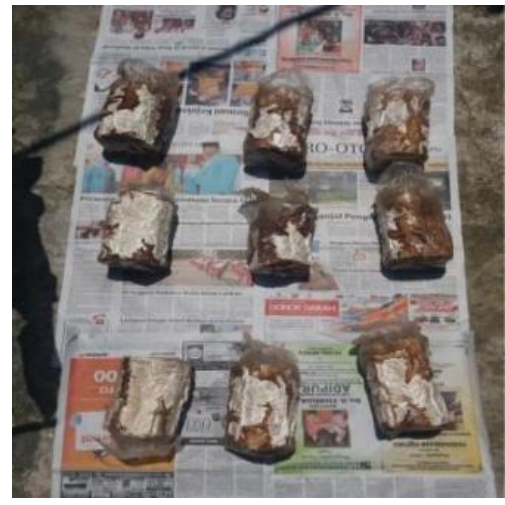

Gambar 2. Penjemur 


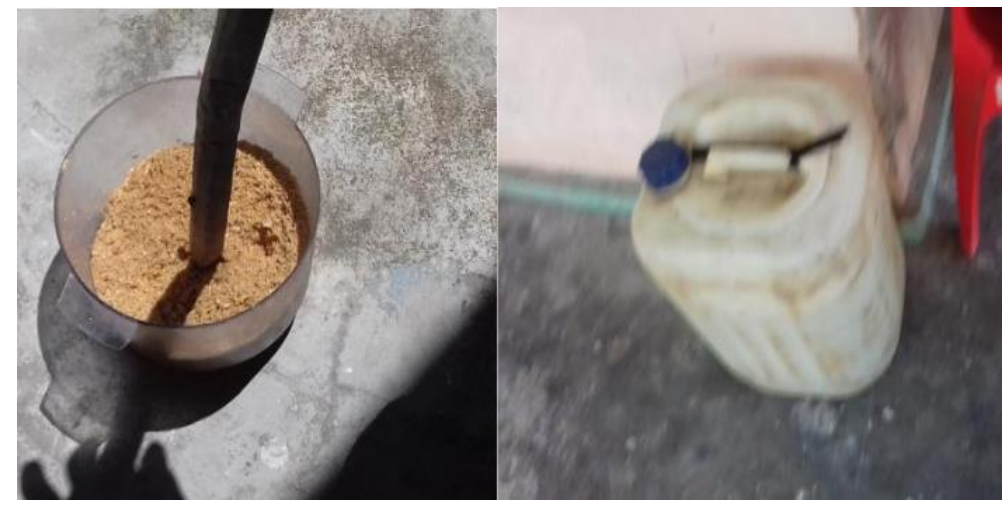

Gambar 3. Penghalusan Limbah Jamur (a) dan Pencampuran Cairan H2SO4 (b)

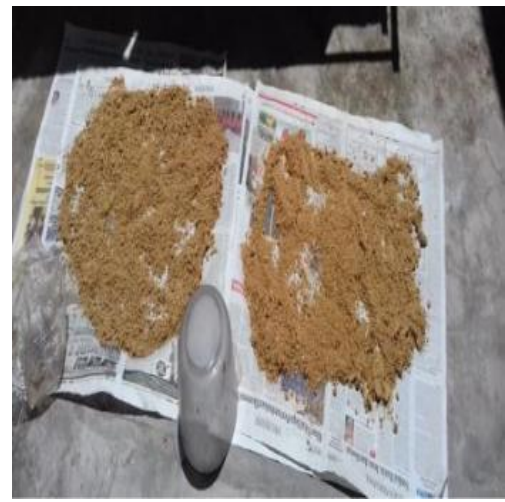

Gambar 4. Penjemuran Hasil Pencampuran Limbah dan Cairan H2SO4

Baglog yang sudah tidak tepakai lagi disisihkan dan dijemur beberapa saat agar bahan baglog tidak terlalu lengket dengan plastik pembungkus baglog. Plastik baglog di lepas dan isi baglog dihaluskan diwadah dengan cara ditumbuk secara manual, setelah haluskan isi baglog dicampurkan denga zat asam dengan perbandingan 1:4. Kemudian didiamkan minimal 1 hari. Isi baglog yang telah bercampur dengan zat asam kemudian dijemur sampai kering. Setelah pengeringan limbah baglog tersebut dibakar dan kemudian dicetak.

\section{Pembuatan Mesin Press Briket}

Pembuatan mesin press ditujukan untuk mencetak dan menyamakan tingkat kepadatan dari hasil penguraian limbah baglog yang dihasilkan untuk menjadi briket oleh Mitra. Sebelum menerima program bantuan PKM ini, Mitra tidak mengetahui apa manfaat dan varian produk yang bisa dibuat dari limbah baglog jamur. Untuk limbah baglog jamur yang sudah tidak terpakai, biasanya dibiarkan atau dibuang begitu saja oleh mitra. Oleh karena itu, dibuatlah mesin press briket yang dapat membantu mencetak dan menyamakan tingkat kepadatan briket, sekaligus dapat mempermudah kerja Mitra dalam membuat briket. Mesin press ini dibuat oleh mahasiswa Politeknik Caltex Riau sebanyak 2 orang dengan menggunakan Workshop Bengkel Mesin yang ada di Politeknik Caltex Riau.
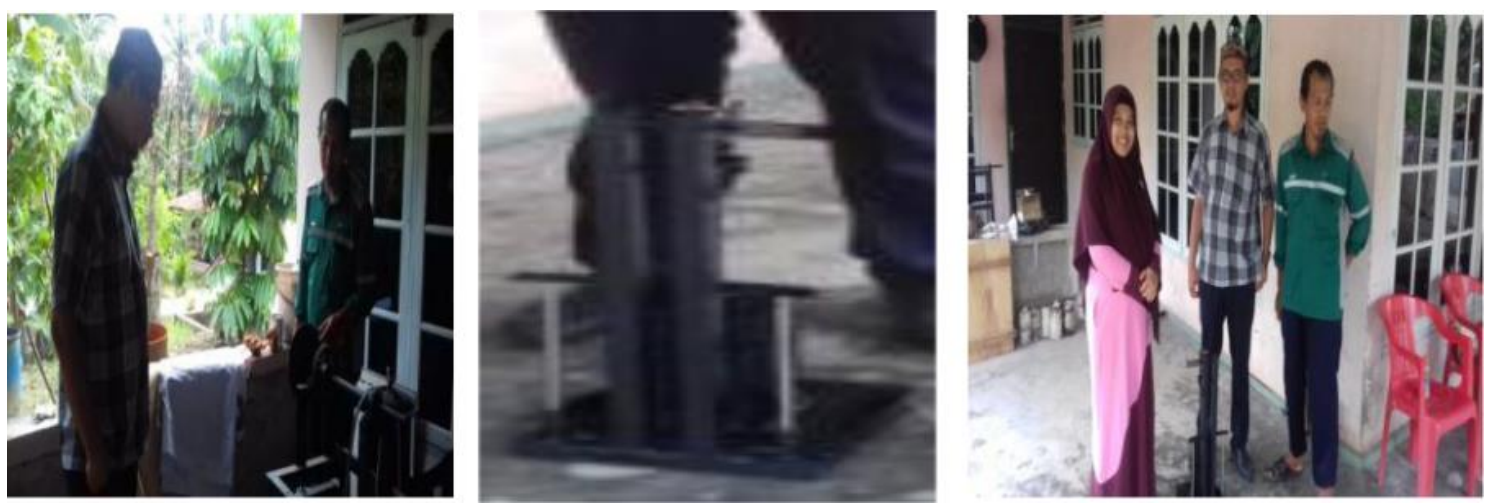

Gambar 4.5 Penyerahan Mesin Press Kepada Mitra 
Mesin press briket ini di desain mempunyai 4 buah tempat cetakan briket limbah baglog jamur dengan bentuk silinder. Cara kerjanya adalah campuran atau hasil penguraian limbah baglog jamur dimasukkan ke cetakkan kemudian cetakkan briket ditutup dengan sambungan cetakkan kemudian di turunkan lengan press cetakkannya, mesin ini didesain secara manual, sehingga tidak membutuhkan konsumsi daya listrik dan cocok untuk industri kecil rumahan seperti milik Mitra. Mesin press yang di desain dapat menghasilkan 4 buah briket dengan kepadatan sesuai yang diharapkan dan waktu sekali proses pengepressan membutuhkan waktu 3 menit. Proses sosialisasi maupun pembuatan briket dari limbah baglog telah dilaksanakan dan dari hasil kegiatan PKM ini perlu diadakan pengujian lebih lanjut akan kadar kalor yang dihasilkan briket limbah baglog yang telah dibuat, agar briket dapat dipasarkan . Untuk peningkatan hasil produksi mitra dapat bertambah sebanyak kurang lebih 1-2 kg, hal ini juga dibantu karena lebih efisien dan rendahnya cost produksi untuk pembibitan dan pembakaran pada saat proses pembibitan karena menggunakan briket yang telah dibuat.

\section{KESIMPULAN}

Sosialisasi tentang Penguraian Limbah Baglog Jamur yang dapat dimanfaatkan sebagai material renewable energi berupa briket dan dapat meningkatkan hasil panen jamur dari petani sebnyak $1-2 \mathrm{~kg}$. Mesin Press briket dapat membantu mencetak dan membuat briket dari limbah baglog jamur. Selain itu dari PKM ini didapatkan luaran penggunaan proses pembakaran menggunakan briket dari hasil olahan limbah baglog jamur, petani juga dapat menghemat cost untuk pembelian bahan bakar (kayu, sekam padi) sebesar Rp. 120.000 untuk proses pemanasan dan steam bibit jamur setiap bulannya.

\section{UCAPAN TERIMA KASIH}

Ucapan terima kasih penulis ucapkan tuntuk UPPM PCR yang telah memberikan bantuan dana hibah internal untuk pengabdian masyarakat sehingga pengusul mampu melaksanakan kegiatan pengabdian masyarakat ini.

\section{DAFTAR PUSTAKA}

Ariyanto. 2016. Daun Jati dan Daun Kakau Sebagai Sumber Energi Alternatif. Dalam prosiding Seminar Nasional XI. Yogyakarta, 4-5 Agustus 2016.

Sinurat, E. 2012. Studi Pemanfaatan Briket Kulit Jambu Mente Dan Tongkol Jagung Sebagai Bahan Bakar Alternatif. Skripsi. Semarang: Universitas Negeri Semarang.

Byeong, I., and Lee. 2015. Kinetic study on the dilute acid catalyzed hydrolysis of waste mushroom medium. Journal of Industrial and Engineering Chemistry 25: 176-179.

Young, J., and L. Woon. 2013. Study on the possibility of waste mushroom medium as a biomass resource for biorefinery. Journal of Industrial and Engineering Chemistry 19: 1535-1539. 